\title{
Pembelajaran Teks Anekdot dengan Menggunakan Media Video Animasi pada Siswa Kelas X SMK Profita Bandung 2018/2019 Wikanengsih ${ }^{1}$, Heri Isnaini ${ }^{2}$, dan Yesi Maylani Kartiwi ${ }^{3}$ \\ Program Studi Pendidikan Bahasa dan Sastra Indonesia, IKIP Siliwangi, Cimahi, Jawa Barat $^{1,2,3}$ wikanengs@yahoo.com $^{1}$ heriisnaini1985@gmail.com $^{2} \underline{\text { Yesi.kartiwi@gmail.com }}^{3}$
}

\begin{abstract}
Abstrak
Artikel ini membahas tentang penggunaan media video animasi pada proses pembelajaran teks anekdot pada siswa kelas X SMK. Penelitian ini difokuskan pada aktivitas siswa dan guru serta perbedaan peningkatan hasil pelaksanaan pembelajarannya. Metode yang digunakan adalah metode eksperimen dengan desain penelitian quasi experiment atau design control group. Pembelajaran teks anekdot dengan menggunakan media video animasi ini dikombinasi dengan metode quantum learning. Hasil yang diperoleh dapat dilihat dari hasil prates dan pascates di kelas kontrol ada perubahan yang signifikan dilihat dari nilai yang dominan meningkat. Prates di kelas kontrol mendapatkan nilai rata-rata 66,73 dan untuk nilai pasca tes mendapatkan nilai ratarata 88,93 Selain itu, terlihat pula peningkatan prates dan pascates di kelas eksperimen. Rata-rata prates adalah 67 dan rata-rata nilai pascates adalah 97,53. Dengan demikian, pembelajaran dengan media ini diharapkan dapat memfasilitasi keterlibatan siswa dalam aktivitas belajar yang tinggi, diharapkan juga kemampuan kreativitas siswa pada pembelajaran teks anekdot. Pada akhirnya, siswa dapat kesempatan untuk mengembangkan diri sesuai dengan kemampuannya masing-masing, yang pada gilirannya nanti minat belajar meningkat, siswa belajar dengan antusias, dan dalam suasana pembelajaran yang menyenangkan.
\end{abstract}

Kata Kunci: pembelajaran, teks anekdot, media video animasi, quantum learning

\section{Pendahuluan}

Pembelajaran berbasis teks merupakan ciri khas dari pembelajaran bahasa Indonesia berdasarkan kurikulum 2013. Pembelajaran berbasis teks dapat dinyatakan pembelajaran yang menjadikan teks sebagai dasar, asas, pangkal, dan tumpuan. Pengertian teks dalam kurikulum 2013 ini berbeda dengan pengertian teks selama ini. Teks selama ini diartikan sebagai wacana tertulis. Dalam kurikulum 2013, teks tidak diartikan sebagai bentuk bahasa tulis. Teks itu adalah ungkapan pikiran manusia yang lengkap yang di dalamnya ada situasi dan konteksnya (Mahsun, 2014: 4).

Selanjutnya, E. Kosasih (2014: 170) mendefinisikan teks sebagai kalimat-kalimat yang teratur dan memiliki keterkaitan. Pengertian ini mendukung pendapat bahwa teks dapat terdiri dari teks tulis dan lisan. Dengan pemberlakukan kurikulum 2013, maka terjadi pergeseran pendekatan pembelajaran Bahasa Indonesia, yakni dari pendekatan komunikatif ke pendekatan teks (genre). Kajian-kajian terhadap teks-teks tersebut mengalami perubahan, yakni teks-teks harus dipelajari secara sistematis dimulai dengan memahami, menginterpretasi, membandingkan, memproduksi, menganalisis, menyunting, mengidentifikasi, mengabstraksi, mengevaluasi, dan mengonversi.

Pada tingkat sekolah menengah atas (SMA, MA, dan SMK) pembelajaran jenis-jenis teks dalam Bahasa Indonesia diperkenalkan 15 teks dengan pembagian 5 teks kelas $\mathrm{X}$ (anekdot, eksposisi, laporan hasil observasi, prosedur kompleks, dan negosiasi), 5 teks kelas XI (cerita pendek, pantun, cerita ulang, eksplanasi, dan ulasan film/drama), dan 5 teks kelas XII (teks cerita sejarah, berita, iklan, editorial, dan cerita fiksi dalam novel). Pada penelitian ini akan difokuskan pada salah satu teks yang diajarkan di kelas X, yakni teks 
anekdot. Kosasih (2014: 178) menjelaskan bahwa teks anekdot merupakan teks yang berisi sindiran atau kritik dibakut dengan kelucuan.

Pembelajaran setiap teks dalam kurikulum 2013 (termasuk teks anekdot) akan disajikan secara sistematis, yakni: memahami, menginterpretasi, membandingkan, memproduksi, menganalisis, menyunting, mengidentifikasi, mengabstraksi, mengevaluasi, dan mengonversi. Pada penelitian ini, teks eksplanasi akan diteliti berdasarkan proses pembelajaran menyunting teks.

Berdasarkan kenyataan hasil pengamatan dan observasi sementara di kelas X SMK Profita Bandung, pembelajaran teks anekdot kurang mencapai hasil yang maksimal, baik dari segi perencanaan, pelaksanaan, maupun hasil. Salah satu faktor utamanya adalah kemampuan bidang kebahasaan dan pembelajaran pada pengalaman sebagai bagian dari sifat kritik yang disajikan oleh teks anekdot. Menurut Arma Husain (2019) pentingnya pengalaman belajar dari orang lain dan pengalaman nyata bagaimana orang lain melakukan pembelajaran sudah sering diungkapkan dalam berbagai literatur, sehingga hal tersebut akan menjadi bagian yang tidak terpisahkan dari pembelajaran teks.

Di samping itu, Penerapan quantum learning diharapkan dapat memfasilitasi keterlibatan siswa dalam aktivitas belajar yang tinggi, diharapkan juga kemampuan kreativitas siswa pada pembelajaran teks. Pada akhirnya, siswa dapat kesempatan untuk mengembangkan diri sesuai dengan kemampuannya masing-masing, yang pada gilirannya nanti minat belajar meningkat, siswa belajar dengan antusias, dan dalam suasana pembelajaran yang menyenangkan. Selain itu, langkah antisipatif yang harus dilakukan untuk meningkat hasil belajar adalah dengan melakukan berbagai variasi dalam pembelajaran (Nirwana \& Ruspa, 2019).

Penggunaan model pembelajaran dengan memanfaatkan teknologi informasi, salah satunya dalam bentuk animasi. Animasi diharapkan dapat menjadi faktor pendorong bagi semangat belajar siswa sehingga siswa tidak merasa bosan ketika mengikuti pelajaran bahasa Indonesia.

Berdasarkan penjelasan tersebut, penelitian ini akan difokuskan pada "Pembelajaran Teks Anekdot dengan Menggunakan Media Video Animasi Pada Siswa Kelas X SMK Profita Bandung 2018/2019”. Adapun rumusan masalah pada penelitian ini adalah sebagai berikut.

1. Bagaimana aktivitas siswa dan guru pada pembelajaran teks anekdot dengan menggunakan media video animasi pada siswa kelas X SMK Profita Bandung?

2. Apakah terdapat perbedaan peningkatan hasil pelaksanaan pembelajaran teks anekdot sebelum dan sesudah menggunakan model video animasi yang dikombinasikan dengan metode quantum learning pada siswa kelas X SMK Profita Bandung?

\section{Tinjauan Pustaka Pembelajaran}

Pembelajaran menurut Winkel (Wartomo, 2016: 14) adalah seperangkat tindakan yang dirancang untuk mendukung proses belajar peserta didik, dengan memperhitungkan kejadian-kejadian eksternal yang berperan terhadap rangkaian kejadian-kejadian internal yang berlangsung di dalam diri peserta didik. Inti dari pembelajaran itu adalah segala upaya yang dilakukan oleh guru (pendidik) agar terjadi proses belajar pada diri siswa. 
Secara implisit di dalam pembelajaran, ada kegiatan memilih, menetapkan dan mengembangkan metode untuk mencapai hasil pembelajaran yang diinginkan. Pembelajaran lebih menekankan pada cara-cara untuk mencapai tujuan dan berkaitan dengan bagaimana cara mengorganisasikan materi pembelajaran, menyampaikan materi pelajaran, dan mengelola pembelajaran.

Ada perbedaan pembelajaran keterampilan Bahasa Indonesia di jenjang SMA dan SMK. Perbedaannya dapat dilihat dari tujuan awal antara SMA dan SMK. Menurut Rostikawati (2014) Sekolah Menengah Kejuruan (SMK) merupakan sekolah yang mencetak lulusan-lulusan siap kerja, sehingga proses pembelajarannya pun harus benar-benar mencetak sosok siswa yang terampil, apalagi keterampilan berbahasa merupakan keterampilan yang wajib dikuasai disetiap jenjang pendidikan, termasuk salah satunya adalah aspek menyunting bahasa. Dengan demikian, pembelajaran harus masuk dan fokus terhadap lulusan dari setiap jenajang satuan Pendidikan.

\section{Teks Anekdot}

Anekdot adalah sebuah cerita singkat yang lucu dan menghibur yang mungkin merupakan pengalaman dari seseorang (Kosasih, 2014: 24). Teks Anekdot bertujuan untuk menghibur pembacanya. Teks Anekdot tidak hanya berisi tentang peristiwa-peristiwa menarik, konyol dan menjengkelkan, melainkan juga berisi tentang ungkapan suatu kebenaran yang lebih umum yang bersifat mengkritik dan menyindir. Teks Anekdot memiliki 5 struktur, diantaranya: Abstraksi, Orientasi, Krisis, Reaksi, dan Koda (Kosasih, 2014: 47).

\section{Media Video Animasi}

Istilah media berasal dari bahasa Latin yang merupakan bentuk jamak dari "medium" yang secara harfiah berarti perantara atau pengantar. Makna adalah semua sesuatu yang dapat menyalurkan informasi dari sumber informasi kepada penerima informasi. Istilah media ini sangat populer dalam bidang komunikasi. Proses belajar mengajar pada dasamya juga merupakan proses komunikasi, sehingga media yang digunakan dalam pembelajaran disebut media pembelajaran.

Adapun kata animasi sendiri berasal dari kata 'to animate' yang berarti menggerakkan,menghidupkan. Misalkan sebuah benda yang mati, lalu digerakkan melalui perubahan sedikit demi sedikit dan teratur sehingga memberikan kesan hidup.animasi adalah proses penciptaan efek gerak atau efek perubahan bentuk yang terjadi selama beberapa waktu. Animasi juga merupakan suatu teknik menampilkan gambar berurut sedemikian rupa sehingga penonton merasakan adanya ilustrasi gerakan (motion) pada gambar yang ditampilkan.

\section{Quantum Learning}

Quantum Learning merupakan kiat, petunjuk, strategi dan seluruh proses belajar yang dapat mempertajam pemahaman dan daya ingat, serta membuat belajar sebagai suatu proses yang menyenangkan dan bermanfaat (Potter \& Hernacki, 2013). Dalam Quantum learning berstandar pada konsep bahwa bawalah dunia mereka ke dunia kita, dan antarkan dunia kita ke dunia mereka. Hal ini menunjukkan, betapa pengajaran dengan Quantum learning tidak hanya menawarkan materi yang mesti dipelajari siswa. Tetapi jauh dari itu, siswa juga diajarkan bagaimana menciptakan hubungan emosional yang baik dalam dan ketika belajar. Quantum learning berfokus pada proses belajar yang menyenangkan. 
Quantum learning menguraikan cara-cara baru yang memudahkan proses belajar melalui pemaduan unsur seni dan pencapaian-pencapaian yang terarah apapun bentuk pelajaranyang diajarkan. Dengan Quantum learning kita dapat mengajar dengan memfungsikan kedua belahan otak kiri dan otak kanan pada fungsinya masing-masing.

\section{Metode Penelitian}

Metode penelitian pada dasarnya merupakan cara ilmiah untuk mendapatkan data dengan tujuan dan kegunaan tertentu. Metode adalah suatu cara yang harus ditempuh untuk mencapai tujuan yang telah ditetapkan (Suharsimi, 2006: 160). Pengguaan teknik yang tepat dapat membantu memecahkan masalah dalam penelitian. Metode yang digunakan adalah metode eksperimen dengan desain penelitian quasi experiment atau design control group. Dalam desain ini terdapat dua kelompok yang masing-masing dipilih secara random. Kelompok pertama diberi perlakuan dan kelompok yang lain tidak. Kelompok yang diberi perlakuan disebut kelompok eksperimen, sedangkan kelompok yang tidak diberi perlakuan disebut kelompok kontrol.

\section{Teknik Penelitian}

Teknik-teknik yang digunakan dalam bentuk penelitian ini terdiri atas: angket atau kuesioner, lembar tes, dan lembar observasi. Angket merupakan suatu teknik pengumpulan data secara tidak langsung (peneliti tidak langsung melakukan tanya jawab dengan responden/siswa). Dalam penelitian ini angket yang dibuat adalah berisi sejumlah petanyaan-pertanyaan yang harus dijawab atau direspon oleh para responden. Responden dalam penelitian ini merupakan siswa yang mendapat perlakuan pembelajaran menyunting teks dengan menggunakan metode quantum learning. Angket peneliti susun agar siswa mampu memberikan jawaban atau respon sesuai dengan persepsinya terhadap hasil dari pembelajaran yang telah dilakukan dalam penelitian ini.

Adapun teknik tes digunakan untuk mengumpulkan data pekerjaan siswa, berupa kemampuan menyunting teks. Dalam penelitian ini peneliti memberikan dua kali tes, yaitu pretes dan postes yang digunakan untuk mengukur kemampuan awal siswa sebelum dan sesudah mendapatkan treatment berupa pembelajaran menyunting teks dengan menggunakan metode quantum learning. Instrumen penelitian yang digunakan dalam penelitian ini adalah essay pretest dan posttest menyunting teks. Pemberian angket digunakan peneliti untuk mengetahui persentase frekuensi pemahaman siswa tentang menyunting teks setelah adanya pembelajaran. Tes digunakan peneliti untuk mengetahui perkembangan kemampuan siswa dalam menyunting teks dengan menggunakan metode quantum learning.

\section{Pembahasan}

\section{A. Analisis Data dan Pembahasan Hasil Penelitian}

\section{Kelas Eksperimen}

Berdasarkan hasil tes awal ini, kelas X BDP 3 sebagai kelas eksperimen, sebelum diberi perlakuan memahami teks Anekdot dengan menggunakan quantum learning, nilai terendah adalah 58 dan nilai tertinggi adalah 79. Adapun siswa yang mendapat nilai tuntas sebanyak 21 siswa dan yang mendapat nilai tidak tuntas sebanyak 9 siswa. 
Hasil Tes Awal (Prates) Kelas Eksperimen Memahami Teks Anekdot

\begin{tabular}{|c|c|c|c|c|c|c|c|c|c|c|c|}
\hline \multirow[t]{4}{*}{ No. } & \multirow[t]{4}{*}{ Nama } & \multicolumn{6}{|c|}{ Aspek yang dinilai } & \multirow[t]{4}{*}{ Jumlah } & \multirow{4}{*}{$\begin{array}{l}\text { Nilai } \\
\text { Akhir }\end{array}$} & \multirow{4}{*}{$\begin{array}{c}\text { Kriteria } \\
\text { Skor }\end{array}$} & \multirow{4}{*}{$\begin{array}{c}\text { Kriteria } \\
\text { Ketuntasan }\end{array}$} \\
\hline & & 1 & 2 & 3 & 4 & 5 & 6 & & & & \\
\hline & & \multicolumn{6}{|c|}{ Bobot Skor } & & & & \\
\hline & & 4 & 4 & 4 & 4 & 4 & 4 & & & & \\
\hline 1 & SIS 1 & 3 & 2 & 3 & 3 & 1 & 2 & 14 & 58 & Bawah & Tidak tuntas \\
\hline 2 & SIS 2 & 3 & 3 & 3 & 3 & 2 & 2 & 16 & 67 & Sedang & Tidak tuntas \\
\hline 3 & SIS 3 & 2 & 4 & 3 & 4 & 3 & 3 & 19 & 79 & Atas & Tuntas \\
\hline 4 & SIS 4 & 3 & 3 & 3 & 3 & 2 & 1 & 15 & 62 & Sedang & Tidak tuntas \\
\hline 5 & SIS 5 & 3 & 3 & 3 & 3 & 2 & 2 & 16 & 67 & Sedang & Tidak tuntas \\
\hline 6 & SIS 6 & 3 & 3 & 3 & 4 & 2 & 3 & 18 & 75 & Atas & Tuntas \\
\hline 7 & SIS 7 & 3 & 3 & 3 & 4 & 1 & 2 & 16 & 67 & Sedang & Tidak tuntas \\
\hline 8 & SIS 8 & 3 & 2 & 3 & 3 & 1 & 2 & 14 & 58 & Bawah & Tidak tuntas \\
\hline 9 & SIS 9 & 3 & 3 & 4 & 3 & 1 & 2 & 16 & 67 & Sedang & Tidak tuntas \\
\hline 10 & SIS 10 & 3 & 3 & 3 & 4 & 1 & 2 & 16 & 67 & Sedang & Tidak tuntas \\
\hline 11 & SIS 11 & 3 & 3 & 3 & 4 & 1 & 3 & 17 & 71 & Atas & Tuntas \\
\hline 12 & SIS 12 & 3 & 3 & 3 & 3 & 2 & 2 & 16 & 67 & Sedang & Tidak tuntas \\
\hline 13 & SIS 13 & 3 & 3 & 3 & 3 & 2 & 2 & 16 & 67 & Sedang & Tidak tuntas \\
\hline 14 & SIS 14 & 3 & 3 & 3 & 3 & 1 & 2 & 15 & 63 & Sedang & Tidak tuntas \\
\hline 15 & SIS 15 & 3 & 3 & 2 & 3 & 1 & 2 & 14 & 58 & Bawah & Tidak tuntas \\
\hline 16 & SIS 16 & 2 & 4 & 3 & 4 & 3 & 3 & 19 & 79 & Atas & Tuntas \\
\hline 17 & SIS 17 & 3 & 3 & 4 & 3 & 1 & 3 & 17 & 71 & Atas & Tuntas \\
\hline 18 & SIS 18 & 3 & 3 & 3 & 3 & 2 & 2 & 16 & 67 & Sedang & Tidak tuntas \\
\hline 19 & SIS 19 & 3 & 4 & 2 & 4 & 3 & 3 & 19 & 79 & Atas & Tuntas \\
\hline 20 & SIS 20 & 3 & 3 & 3 & 2 & 1 & 2 & 14 & 58 & Bawah & Tidak tuntas \\
\hline 21 & SIS 21 & 3 & 2 & 3 & 3 & 1 & 2 & 14 & 58 & Bawah & Tidak tuntas \\
\hline 22 & SIS 22 & 3 & 3 & 3 & 3 & 2 & 2 & 16 & 67 & Sedang & Tidak tuntas \\
\hline 23 & SIS 23 & 3 & 3 & 3 & 4 & 1 & 2 & 16 & 67 & Sedang & Tidak tuntas \\
\hline 24 & SIS 24 & 3 & 3 & 2 & 3 & 1 & 2 & 14 & 58 & Bawah & Tidak tuntas \\
\hline 25 & SIS 25 & 3 & 3 & 3 & 3 & 1 & 2 & 15 & 63 & Sedang & Tidak tuntas \\
\hline 26 & SIS 26 & 3 & 3 & 4 & 3 & 3 & 3 & 19 & 79 & Atas & Tuntas \\
\hline 27 & SIS 27 & 3 & 3 & 4 & 4 & 2 & 2 & 18 & 75 & Atas & Tuntas \\
\hline 28 & SIS 28 & 3 & 3 & 4 & 4 & 1 & 2 & 17 & 71 & Atas & Tuntas \\
\hline 29 & SIS 29 & 3 & 3 & 3 & 2 & 1 & 2 & 14 & 58 & Bawah & Tidak tuntas \\
\hline 30 & SIS 30 & 3 & 3 & 4 & 3 & 1 & 2 & 16 & 67 & Sedang & Tidak tuntas \\
\hline \multicolumn{8}{|c|}{ Jumlah } & 482 & 2010 & & \\
\hline \multicolumn{8}{|c|}{ Rata-rata } & 16.06 & 67 & & \\
\hline
\end{tabular}

Setelah melihat hasil data tes awal (prates) memahami teks ekplanasi, selanjutnya penulis menyajikan tabel distribusi frekuensi untuk mengetahui rata-rata nilai tes awal (prates) siswa kelas X BDP 3 SMK Profita Bandung 


\section{Distribusi Frekuensi Nilai Tes Awal (Prates) Kelas Eksperimen}

\begin{tabular}{|c|c|c|}
\hline Nilai & Frekuensi & Jumlah \\
\hline 14 & 7 & 98 \\
\hline 15 & 3 & 45 \\
\hline 16 & 11 & 176 \\
\hline 17 & 3 & 51 \\
\hline 18 & 2 & 36 \\
\hline 19 & 4 & 76 \\
\hline Jumlah & 30 & 482 \\
\hline Rata-rata & \multicolumn{2}{|c|}{$482: 30=16,06$} \\
\hline
\end{tabular}

Hasil Tes Akhir (Pascates) Kelas Eksperimen Memahami Teks Anekdot

\begin{tabular}{|c|c|c|c|c|c|c|c|c|c|c|c|}
\hline \multirow[t]{4}{*}{ No. } & \multirow[t]{4}{*}{ Nama } & \multicolumn{6}{|c|}{ Aspek yang dinilai } & \multirow[t]{4}{*}{ Jumlah } & \multirow{4}{*}{$\begin{array}{l}\text { Nilai } \\
\text { Akhir }\end{array}$} & \multirow{4}{*}{$\begin{array}{l}\text { Kriteria } \\
\text { Skor }\end{array}$} & \multirow{4}{*}{$\begin{array}{c}\text { Kriteria } \\
\text { Ketuntasan }\end{array}$} \\
\hline & & 1 & 2 & 3 & 4 & 5 & 6 & & & & \\
\hline & & \multicolumn{6}{|c|}{ Bobot Skor } & & & & \\
\hline & & 4 & 4 & 4 & 4 & 4 & 4 & & & & \\
\hline 1 & SIS 1 & 4 & 4 & 4 & 4 & 3 & 4 & 23 & 96 & Atas & Tuntas \\
\hline 2 & SIS 2 & 4 & 4 & 4 & 4 & 3 & 3 & 22 & 92 & Sedang & Tuntas \\
\hline 3 & SIS 3 & 3 & 4 & 4 & 4 & 3 & 4 & 22 & 92 & Sedang & Tuntas \\
\hline 4 & SIS 4 & 4 & 4 & 4 & 4 & 3 & 4 & 23 & 96 & Atas & Tuntas \\
\hline 5 & SIS 5 & 4 & 4 & 4 & 4 & 3 & 4 & 23 & 96 & Atas & Tuntas \\
\hline 6 & SIS 6 & 4 & 4 & 4 & 4 & 3 & 4 & 23 & 96 & Atas & Tuntas \\
\hline 7 & SIS 7 & 4 & 4 & 4 & 4 & 3 & 4 & 23 & 96 & Atas & Tuntas \\
\hline 8 & SIS 8 & 4 & 4 & 4 & 4 & 3 & 4 & 23 & 96 & Atas & Tuntas \\
\hline 9 & SIS 9 & 4 & 4 & 4 & 4 & 3 & 4 & 23 & 96 & Atas & Tuntas \\
\hline 10 & SIS 10 & 4 & 4 & 4 & 4 & 3 & 4 & 23 & 96 & Atas & Tuntas \\
\hline 11 & SIS 11 & 4 & 4 & 4 & 4 & 4 & 4 & 24 & 100 & Atas & Tuntas \\
\hline 12 & SIS 12 & 4 & 4 & 4 & 4 & 3 & 4 & 23 & 96 & Atas & Tuntas \\
\hline 13 & SIS 13 & 4 & 4 & 4 & 4 & 3 & 4 & 23 & 96 & Atas & Tuntas \\
\hline 14 & SIS 14 & 4 & 4 & 4 & 4 & 3 & 4 & 23 & 96 & Atas & Tuntas \\
\hline 15 & SIS 15 & 4 & 4 & 4 & 4 & 3 & 4 & 23 & 96 & Atas & Tuntas \\
\hline 16 & SIS 16 & 4 & 4 & 4 & 4 & 3 & 3 & 22 & 92 & Sedang & Tuntas \\
\hline 17 & SIS 17 & 4 & 4 & 4 & 4 & 3 & 3 & 22 & 92 & Sedang & Tuntas \\
\hline 18 & SIS 18 & 4 & 4 & 4 & 4 & 3 & 4 & 23 & 96 & Atas & Tuntas \\
\hline 19 & SIS 19 & 4 & 4 & 4 & 4 & 3 & 3 & 22 & 92 & Sedang & Tuntas \\
\hline 20 & SIS 20 & 4 & 4 & 4 & 4 & 3 & 4 & 23 & 96 & Atas & Tuntas \\
\hline 21 & SIS 21 & 4 & 4 & 4 & 4 & 3 & 4 & 23 & 96 & Atas & Tuntas \\
\hline 22 & SIS 22 & 4 & 4 & 4 & 4 & 3 & 4 & 23 & 96 & Atas & Tuntas \\
\hline 23 & SIS 23 & 4 & 4 & 4 & 4 & 3 & 3 & 22 & 92 & Sedang & Tuntas \\
\hline 24 & SIS 24 & 4 & 4 & 4 & 4 & 3 & 4 & 23 & 96 & Atas & Tuntas \\
\hline 25 & SIS 25 & 4 & 4 & 4 & 4 & 2 & 2 & 20 & 83 & Bawah & Tuntas \\
\hline 26 & SIS 26 & 4 & 4 & 4 & 4 & 4 & 4 & 24 & 100 & Atas & Tuntas \\
\hline 27 & SIS 27 & 4 & 4 & 4 & 3 & 2 & 3 & 20 & 83 & Bawah & Tuntas \\
\hline 28 & SIS 28 & 4 & 4 & 4 & 4 & 3 & 4 & 23 & 96 & Atas & Tuntas \\
\hline 29 & SIS 29 & 4 & 4 & 4 & 4 & 3 & 4 & 23 & 96 & Atas & Tuntas \\
\hline 30 & SIS 30 & 4 & 4 & 4 & 4 & 2 & 3 & 21 & 88 & Bawah & Tuntas \\
\hline & & & lah & & & & & 682 & 2926 & & \\
\hline & & Rat & $\mathrm{ra}$ & & & & & 22,73 & 97,53 & & \\
\hline
\end{tabular}


Berdasarkan hasil tes akhir, kelas X BDP 3 sebagai kelas eksperimen, setelah diberi perlakuan memahami teks Anekdot dengan menggunakan quantum learning, nilai terendah adalah 83 dan nilai tertinggi adalah 100. Siswa yang mendapat nilai tuntas sebanyak 30. siswa

Distribusi Frekuensi Nilai Tes Akhir (Pascates) Kelas Eksperimen
\begin{tabular}{|c|c|c|}
\hline Nilai & Frekuensi & Jumlah \\
\hline 20 & 2 & 40 \\
\hline 21 & 1 & 21 \\
\hline 22 & 6 & 136 \\
\hline 23 & 19 & 437 \\
\hline 24 & 2 & 48 \\
\hline Jumlah & 30 & 682 \\
\hline Rata-rata & \multicolumn{2}{|c|}{$682: 30=22,73$} \\
\hline
\end{tabular}

Hasil Tes Awal (Prates) Kelas Kontrol Memahami Teks Anekdot

\begin{tabular}{|c|c|c|c|c|c|c|c|c|c|c|c|}
\hline \multirow[t]{4}{*}{ No. } & \multirow[t]{4}{*}{ Nama } & \multicolumn{6}{|c|}{ Aspek yang dinilai } & \multirow[t]{4}{*}{ Jumlah } & \multirow{4}{*}{$\begin{array}{c}\text { Nilai } \\
\text { Akhir }\end{array}$} & \multirow{4}{*}{$\begin{array}{c}\text { Kriteria } \\
\text { Skor }\end{array}$} & \multirow{4}{*}{$\begin{array}{c}\text { Kriteria } \\
\text { Ketuntasan }\end{array}$} \\
\hline & & 1 & 2 & 3 & 4 & 5 & 6 & & & & \\
\hline & & \multicolumn{6}{|c|}{ Bobot Skor } & & & & \\
\hline & & 4 & 4 & 4 & 4 & 4 & 4 & & & & \\
\hline 1 & SIS 1 & 3 & 3 & 3 & 3 & 3 & 3 & 18 & 75 & Atas & Tuntas \\
\hline 2 & SIS 2 & 2 & 3 & 2 & 2 & 3 & 2 & 14 & 58 & Bawah & Tidak tuntas \\
\hline 3 & SIS 3 & 3 & 2 & 2 & 3 & 2 & 2 & 14 & 58 & Bawah & Tidak tuntas \\
\hline 4 & SIS 4 & 2 & 2 & 3 & 2 & 2 & 3 & 14 & 58 & Bawah & Tidak tuntas \\
\hline 5 & SIS 5 & 2 & 3 & 2 & 2 & 3 & 2 & 14 & 58 & Bawah & Tidak tuntas \\
\hline 6 & SIS 6 & 3 & 2 & 2 & 3 & 2 & 2 & 14 & 58 & Bawah & Tidak tuntas \\
\hline 7 & SIS 7 & 3 & 3 & 3 & 4 & 3 & 1 & 17 & 71 & Sedang & Tuntas \\
\hline 8 & SIS 8 & 3 & 3 & 3 & 4 & 3 & 3 & 19 & 79 & Atas & Tuntas \\
\hline 9 & SIS 9 & 2 & 2 & 2 & 3 & 2 & 2 & 13 & 54 & Bawah & Tidak tuntas \\
\hline 10 & SIS 10 & 3 & 3 & 4 & 3 & 3 & 1 & 17 & 71 & Sedang & Tuntas \\
\hline 11 & SIS 11 & 2 & 3 & 3 & 4 & 3 & 2 & 17 & 71 & Sedang & Tuntas \\
\hline 12 & SIS 12 & 2 & 2 & 3 & 4 & 3 & 3 & 17 & 71 & Sedang & Tuntas \\
\hline 13 & SIS 13 & 3 & 2 & 3 & 3 & 2 & 2 & 15 & 63 & Sedang & Tidak tuntas \\
\hline 14 & SIS 14 & 3 & 4 & 3 & 3 & 3 & 3 & 19 & 79 & Atas & Tuntas \\
\hline 15 & SIS 15 & 3 & 4 & 3 & 3 & 4 & 3 & 20 & 83 & Atas & Tuntas \\
\hline 16 & SIS 16 & 2 & 3 & 3 & 3 & 4 & 2 & 17 & 71 & Sedang & Tuntas \\
\hline 17 & SIS 17 & 3 & 3 & 3 & 3 & 4 & 3 & 15 & 79 & Atas & Tuntas \\
\hline 18 & $\begin{array}{l}\text { SIS } 18 \\
\end{array}$ & 3 & 3 & 4 & 3 & 2 & 2 & 17 & 71 & $\mathrm{At}_{\mathrm{i}}$ & tas \\
\hline 19 & SIS 19 & 2 & 3 & 2 & 2 & 3 & 2 & 1 & 58 & Bawah & \\
\hline 20 & SIS 20 & 2 & 3 & 3 & 4 & 3 & 2 & 17 & 71 & Sedang & Tuntas \\
\hline 21 & SIS 21 & 3 & 3 & 3 & 4 & 3 & 3 & 19 & 79 & Atas & Tuntas \\
\hline 22 & SIS 22 & 2 & 3 & 3 & 4 & 3 & 2 & 17 & 71 & Sedang & Tuntas \\
\hline 23 & SIS 23 & 2 & 2 & 2 & 3 & 2 & 2 & 13 & 54 & Bawah & Tidak tuntas \\
\hline 24 & SIS 24 & 2 & 4 & 3 & 4 & 3 & 3 & 19 & 79 & Atas & Tuntas \\
\hline 25 & SIS 25 & 2 & 4 & 3 & 4 & 3 & 2 & 18 & 75 & Atas & Tuntas \\
\hline 26 & SIS 26 & 3 & 3 & 2 & 3 & 2 & 2 & 15 & 63 & Sedang & Tidak tuntas \\
\hline 27 & SIS 27 & 2 & 3 & 2 & 2 & 3 & 2 & 14 & 58 & Bawah & Tidak tuntas \\
\hline 28 & SIS 28 & 2 & 2 & 3 & 2 & 3 & 2 & 14 & 58 & Bawah & Tidak tuntas \\
\hline 29 & SIS 29 & 2 & 2 & 2 & 2 & 3 & 2 & 13 & 54 & Bawah & Tidak tuntas \\
\hline 30 & SIS 30 & 2 & 3 & 2 & 2 & 2 & 2 & 13 & 54 & Bawah & Tidak tuntas \\
\hline \multicolumn{8}{|c|}{ Jumlah } & 481 & 2002 & & \\
\hline \multicolumn{8}{|c|}{ Rata-rata } & 16,03 & 66,73 & & \\
\hline
\end{tabular}


Setelah melihat hasil data tes awal (prates) memahami teks anekdot, selanjutnya penulis menyajikan tabel distribusi frekuensi untuk mengetahui rata-rata nilai tes awal (prates) siswa kelas X BDP 4 SMK Profita Bandung.

Distribusi Frekuensi Nilai Tes Awal (Prates) Kelas Kontrol

\begin{tabular}{|c|c|c|}
\hline Nilai (x) & Frekuensi (f) & Jumlah (fx) \\
\hline 13 & 4 & 52 \\
\hline 14 & 8 & 112 \\
\hline 15 & 2 & 30 \\
\hline 17 & 8 & 136 \\
\hline 18 & 2 & 36 \\
\hline 19 & 5 & 95 \\
\hline 20 & 1 & 20 \\
\hline Jumlah & 30 & 481 \\
\hline Rata-rata & \multicolumn{2}{|c|}{$481: 30=16,03$} \\
\hline
\end{tabular}

Hasil Tes Akhir (Pascates) Kelas Kontrol Memahami Teks Anekdot

\begin{tabular}{|c|c|c|c|c|c|c|c|c|c|c|c|}
\hline \multirow[t]{4}{*}{ No. } & \multirow[t]{4}{*}{ Nama } & \multicolumn{6}{|c|}{ Aspek yang dinilai } & \multirow[t]{4}{*}{ Jumlah } & \multirow{4}{*}{$\begin{array}{c}\text { Nilai } \\
\text { Akhir }\end{array}$} & \multirow{4}{*}{$\begin{array}{c}\text { Kriteria } \\
\text { Skor }\end{array}$} & \multirow{4}{*}{$\begin{array}{c}\text { Kriteria } \\
\text { Ketuntasan }\end{array}$} \\
\hline & & 1 & 2 & 3 & 4 & 5 & 6 & & & & \\
\hline & & \multicolumn{6}{|c|}{ Bobot Skor } & & & & \\
\hline & & 4 & 4 & 4 & 4 & 4 & 4 & & & & \\
\hline 1 & SIS 1 & 4 & 4 & 4 & 4 & 3 & 3 & 22 & 92 & Atas & Tuntas \\
\hline 2 & SIS 2 & 3 & 4 & 4 & 3 & 3 & 3 & 20 & 83 & Bawah & Tuntas \\
\hline 3 & SIS 3 & 3 & 3 & 4 & 4 & 3 & 3 & 20 & 83 & Bawah & Tuntas \\
\hline 4 & SIS 4 & 3 & 4 & 4 & 4 & 3 & 3 & 21 & 88 & Sedang & Tuntas \\
\hline 5 & SIS 5 & 4 & 4 & 4 & 4 & 3 & 4 & 23 & 96 & Atas & Tuntas \\
\hline 6 & SIS 6 & 4 & 4 & 4 & 3 & 3 & 3 & 21 & 88 & Sedang & Tuntas \\
\hline 7 & SIS 7 & 4 & 4 & 4 & 4 & 3 & 3 & 22 & 92 & Atas & Tuntas \\
\hline 8 & SIS 8 & 3 & 3 & 4 & 4 & 3 & 3 & 20 & 83 & Bawah & Tuntas \\
\hline 9 & SIS 9 & 4 & 4 & 4 & 4 & 2 & 4 & 22 & 92 & Atas & Tuntas \\
\hline 10 & SIS 10 & 3 & 4 & 4 & 4 & 3 & 3 & 21 & 88 & Sedang & Tuntas \\
\hline 11 & SIS 11 & 4 & 4 & 4 & 4 & 3 & 3 & 22 & 92 & Atas & Tuntas \\
\hline 12 & SIS 12 & 4 & 3 & 3 & 4 & 3 & 3 & 20 & 83 & Bawah & Tuntas \\
\hline 13 & SIS 13 & 3 & 4 & 4 & 4 & 3 & 3 & 21 & 88 & Sedang & Tuntas \\
\hline 14 & SIS 14 & 3 & 4 & 4 & 4 & 3 & 3 & 21 & 88 & Sedang & Tuntas \\
\hline 15 & SIS 15 & 3 & 4 & 4 & 4 & 3 & 3 & 21 & 88 & Sedang & Tuntas \\
\hline 16 & SIS 16 & 3 & 3 & 4 & 4 & 3 & 3 & 20 & 83 & Bawah & Tuntas \\
\hline 17 & SIS 17 & 3 & 4 & 4 & 4 & 3 & 3 & 21 & 88 & Sedang & Tuntas \\
\hline 18 & SIS 18 & 3 & 3 & 4 & 4 & 3 & 4 & 21 & 88 & Sedang & Tuntas \\
\hline 19 & SIS 19 & 3 & 3 & 4 & 4 & 3 & 3 & 20 & 83 & Bawah & Tuntas \\
\hline 20 & SIS 20 & 3 & 4 & 4 & 4 & 3 & 3 & 21 & 88 & Sedang & Tuntas \\
\hline 21 & SIS 21 & 4 & 4 & 4 & 4 & 3 & 4 & 23 & 96 & Atas & Tuntas \\
\hline 22 & SIS 22 & 4 & 4 & 4 & 4 & 3 & 4 & 23 & 96 & Atas & Tuntas \\
\hline 23 & SIS 23 & 4 & 3 & 4 & 4 & 3 & 3 & 21 & 88 & Sedang & Tuntas \\
\hline 24 & SIS 24 & 4 & 4 & 4 & 4 & 3 & 4 & 23 & 96 & Atas & Tuntas \\
\hline 25 & SIS 25 & 4 & 4 & 4 & 4 & 3 & 4 & 23 & 96 & Atas & Tuntas \\
\hline 26 & SIS 26 & 4 & 3 & 3 & 4 & 3 & 3 & 20 & 83 & Bawah & Tuntas \\
\hline 27 & SIS 27 & 4 & 4 & 4 & 4 & 4 & 4 & 24 & 100 & Atas & Tuntas \\
\hline 28 & SIS 28 & 3 & 4 & 4 & 4 & 3 & 3 & 21 & 88 & Sedang & Tuntas \\
\hline 29 & SIS 29 & 3 & 3 & 4 & 4 & 3 & 3 & 20 & 83 & Bawah & Tuntas \\
\hline 30 & SIS 30 & 4 & 4 & 3 & 4 & 3 & 3 & 21 & 88 & Sedang & Tuntas \\
\hline & & & lah & & & & & 639 & 2668 & & \\
\hline & & Rat: & -ra & & & & & 21,3 & 88,93 & & \\
\hline
\end{tabular}


Berdasarkan hasil tes akhir, kelas X BDP 4 sebagai kelas kontrol, sebelum diberi perlakuan memahami teks Anekdot dengan menggunakan quantum learning, nilai terendah adalah 83 dan nilai tertinggi adalah 100. Adapun siswa yang mendapat nilai tuntas sebanyak 30 siswa.

\section{Distribusi Frekuensi Nilai Tes Akhir (pascates) Kelas Kontrol}

\begin{tabular}{|c|c|c|}
\hline Nilai & Frekuensi & Jumlah \\
\hline 20 & 8 & 160 \\
\hline 21 & 12 & 252 \\
\hline 22 & 4 & 88 \\
\hline 23 & 5 & 115 \\
\hline 24 & 1 & 24 \\
\hline Jumlah & 30 & 639 \\
\hline Rata-rata & \multicolumn{2}{|c|}{$639: 30=21,3$} \\
\hline
\end{tabular}

Dengan demikian, hasil prates dan postes di kelas kontrol ada perubahan yang signifikan dilihat dari nilai yang dominan meningkat. Prates di kelas kontrol mendapatkan nilai rata-rata 66,73 dan untuk nilai pasca tes mendapatkan nilai rata-rata 88,93 . Selain itu, terlihat pula peningkatan prates dan postes di kelas eksperimen. Rata-rata prates adalah 67 dan rata-rata nilai pascates adalah 97,53

Berdasarkan hasil rata-rata nilai prates dan pascates kelas eksperimen dan kelas kontrol, dapat digambarkan secara jelas melalui grafik berikut.

\section{Perbandingan skor kelas eksperimen dan kelas kontrol}

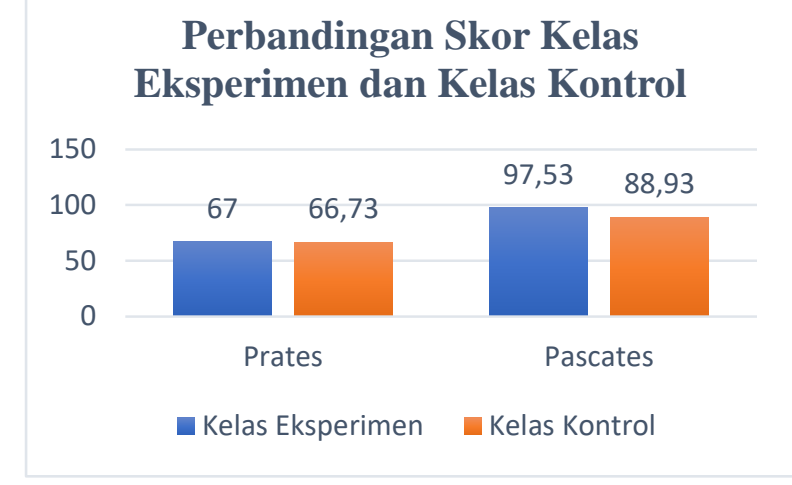

\section{Analisis Statistika Hasil Data}

Untuk menguji hipotesis-hipotesis penelitian, maka selanjutnya akan dilakukan uji statistik dengan menggunakan software SPSS 22 di bawah ini:

\section{Analisis Kemampuan Memahami Teks Anekdot Tes Awal/Prates Kelas Eksperimen dan Kelas Kontrol}

Untuk mengetahui bahwa kemampuan awal kelas eksperimen dan kelas kontrol tidak jauh berbeda secara signifikan, maka dilakukan uji perbedaan rata-rata (2 pihak) 
hasil prates, tetapi sebelum melakukan uji perbedaan rata-rata, terlebih dahulu dilakukan uji normalitas sebagai persyaratan untuk melakukan uji statistik yang digunakan.

a. Uji Normalitas Data Prates

Hasil Output Uji Normalitas Data Prates

Tests of Normality

\section{hasil Output Uji Normalitas Data Prates}

\begin{tabular}{|l|l|l|l|l|l|l|}
\hline & \multicolumn{3}{|l|}{ Kolmogov-Smirnov ${ }^{\mathrm{a}}$} & \multicolumn{3}{l|}{ Shapiro-Wilk } \\
\cline { 2 - 7 } & Statistic & Df & Sig. & Statistic & Df & Sig. \\
\hline kelas_eksperime &, 200 & 30 &, 004 &, 891 & 30 &, 005 \\
n &, 222 & 30 &, 001 &, 884 & 30 &, 003 \\
kelas_kontrol &, 222 &
\end{tabular}

a. Lilliefors Significance Correction

Keterangan:

Berdasarkan tabel di atas, diperoleh hasil uji normalitas yaitu untuk kelas eksperimen sebesar 0,004, artinya lebih kecil dari 0,05 dan kelas kontrol sebesar 0,001, artinya lebih kecil dari 0,05. Karena nilai keduanya nilai signifikansi kurang dari 0,05 maka data tersebut berdistribusi tidak normal, maka selanjutnya dilakukan uji non parametrik Mann-Whitney. Untuk lebih jelas dapat dilihat pada grafik di bawah ini:

\section{Q-Q Plot Kelas Eksperimen}

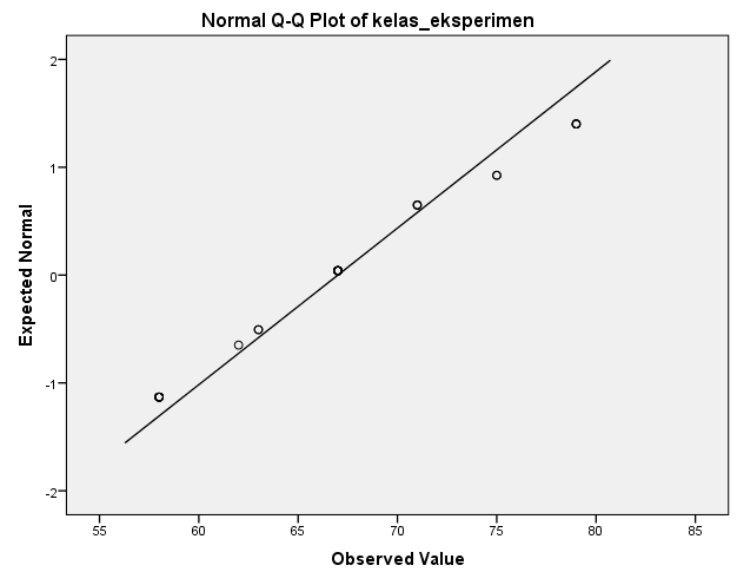

Output pada grafik di atas untuk melihat normalitas data. Data berdistribusi tidak normal jika ada sebagian data yang tidak di sekitar garis namun mengikuti arah diagonal garis. Data-data yang jauh dari garis maka data-data tersebut termasuk outliner. Dengan demikian, berdasarkan grafik di atas, distribusi tes awal untuk kelas eksperimen tidak normal. 


\section{Q-Q Plot Kelas Kontrol}

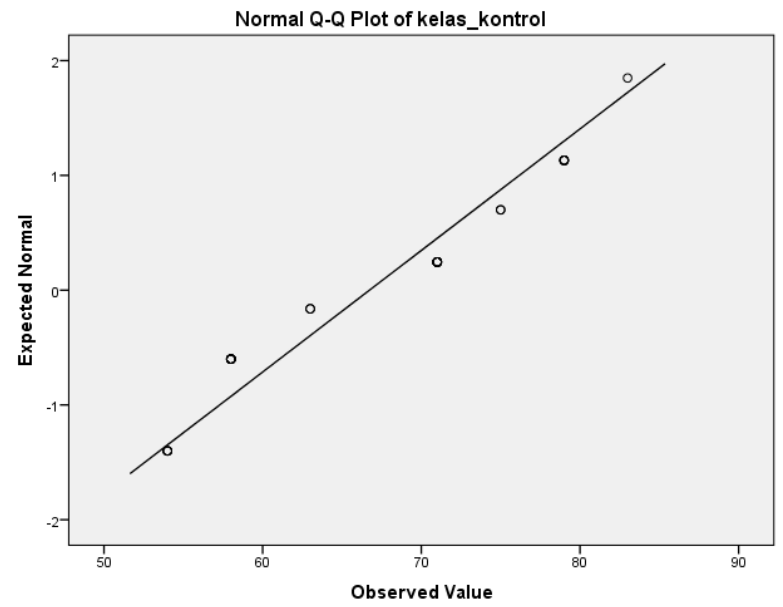

Output pada grafik di atas untuk melihat normalitas data. Data berdistribusi tidak normal jika ada sebagian data yang tidak di sekitar garis namun mengikuti arah diagonal garis. Data-data yang jauh dari garis maka data-data tersebut termasuk outliner. Dengan demikian, berdasarkan grafik di atas, distribusi tes awal untuk kelas kontrol tidak normal.

b. Two Independent Sample Test dengan Uji Mann-Whitney Data Prates

Uji Two Independent Sample Tests atau uji 2 sampel bebas digunakan untuk mengetahui ada tidaknya perbedaan antara dua kelompok data yang independen. Uji ini dapat digunakan sebagai alternatif pengganti dari analisis parametrik, yaitu Independent Sample T Test jika data tidak berdistribusi normal dengan uji Mann-Whitney. Analisis ini termasuk non parametrik sehingga tidak mensyaratkan data berdistribusi normal.

Karena sampel berdistribusi tidak normal, maka dilanjutkan pengujian non parametrik Mann-Whitney, dengan menggunakan hipotesis statistik sebagai berikut:

Ho : tidak ada perbedaan kemampuan awal kelas eksperimen dan kelas kontrol Ha : ada perbedaan kemampuan awal kelas eksperimen dan kelas kontrol Kriteria pengujian:

Jika nilai sig $>0,05$ maka Ho diterima Jika nilai sig $<0,05$ maka Ha ditolak 
Hasil Analisis Uji Mann-Whitney Prates

Test Statistics
\begin{tabular}{|llll|l|}
\hline \multicolumn{2}{|c|}{} & & Prates \\
\hline Mann-Whitney U & & & 446,000 \\
Wilcoxon W & & 911,000 \\
Z & &,- 060 \\
Asymp. Sig. (2-tailed) & &, 952 \\
Monte Carlo Sig. (2- Sig. & &, $956^{\mathrm{b}}$ \\
tailed) & $95 \%$ & Confidence & Lower &, 952 \\
& Interval & Bound & \\
& & Upper &, 960 \\
Monte Carlo Sig. (1- Sig. & Bound &, $480^{\mathrm{b}}$ \\
tailed) & $95 \%$ & Confidence & Lower &, 470 \\
& Interval & Bound & \\
& & Upper &, 489 \\
\hline
\end{tabular}

Hasil Analisis Uji Mann-Whitney Prates

a. Grouping Variable: kelas

Keterangan:

b. Based on 10000 sampled tables with starting seed 2000000 .

Berdasarkan tabel di atas terlihat bahwa nilai signifikansi (Asymp. Sig) sebesar 0,952 artinya > 0,05 sehingga Ho diterima, maka dapat disimpulkan bahwa tidak terdapat perbedaan kemampuan awal siswa kelas eksperimen dan kelas kontrol.

\section{Analisis Kemampuan Memahami Teks Anekdot Tes akhir/Pascates Kelas Eksperimen dan Kelas Kontrol}

Setelah melakukan tes awal dan setiap kelas diberikan pembelajaran memahami teks Anekdot dengan metode yang berbeda maka akan diperoleh hasil dari tes akhir. Untuk menganalisis secara statistik hasil tes akhir (pascates) antara kelas eksperimen dan kelas kontrol, langkah-langkahnya sama seperti saat perhitungan statistik analisis tes awal (prates).

a. Uji normalitas pascates

Uji normalitas terhadap kelas eksperimen dan kelas kontrol dilakukan dengan uji Kolmogorof Smirnov menggunakan program SPSS 22. Pedoman pengambilan keputusan dengan mengambil taraf signifikansi $5 \%$ adalah sebagai berikut:

a) Nilai signifikan (sig) $<0,05$ maka Ho ditolak artinya berdistribusi tidak normal

b) Nilai signifikan (sig) > 0,05 maka Ho diterima artinya berdistribusi normal Maka hipotesis statistik sebagai berikut:

Ho : data berdistribusi normal

Ha : data tidak berdistribusi normal 


\section{Hasil Analisis Uji Normalitas Pascates Kelas Eksperimen dan Kelas Kontrol Tests of Normality}

\begin{tabular}{|l|l|l|l|l|l|l|}
\hline \multirow{2}{*}{} & \multicolumn{3}{|l|}{ Kolmogorov-Smirnov $v^{\mathrm{a}}$} & \multicolumn{3}{l|}{ Shapiro-Wilk } \\
\cline { 2 - 7 } & Statistic & Df & Sig. & Statistic & Df & Sig. \\
\hline kelas_eksperime &, 364 & 30 &, 000 &, 722 & 30 &, 000 \\
n &, 242 & 30 &, 000 &, 877 & 30 &, 002 \\
kelas_kontrol &, 247 \\
\hline
\end{tabular}

a. Lilliefors Significance Correction

Berdasarkan tabel di atas terlihat bahwa nilai signifikansi untuk kelas eksperimen sebesar 0,000 artinya lebih kecil dari 0,05 dan kelas kontrol sebesar 0,000 artinya lebih kecil dari 0,05. Karena nilai signifikansi kurang dari 0,05 maka data tersebut tidak berdistribusi normal, selanjutnya dilakukan uji non parametrik Mann-Whitney.

\section{Q-Q Plot Kelas Eksperimen}

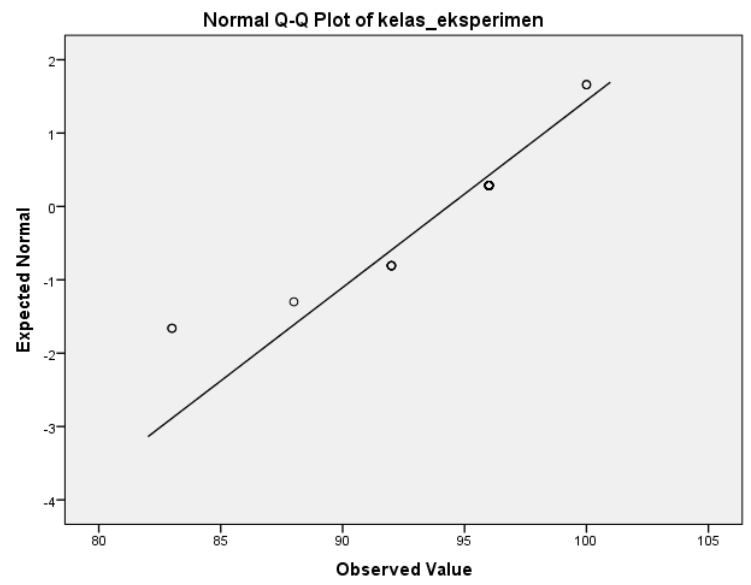

Output grafik di atas untuk melihat normalitas data. Distribusi data tidak normal jika ada sebagian data yang tidak di sekitar garis namun mengikuti arah diagonal garis. Data-data yang jauh dari garis maka data-data tersebut termasuk outliner. Dengan demikian, berdasarkan grafik di atas distribusi tes akhir untuk kelas eksperimen tidak normal. 


\section{Q-Q Plot Kelas Kontrol}

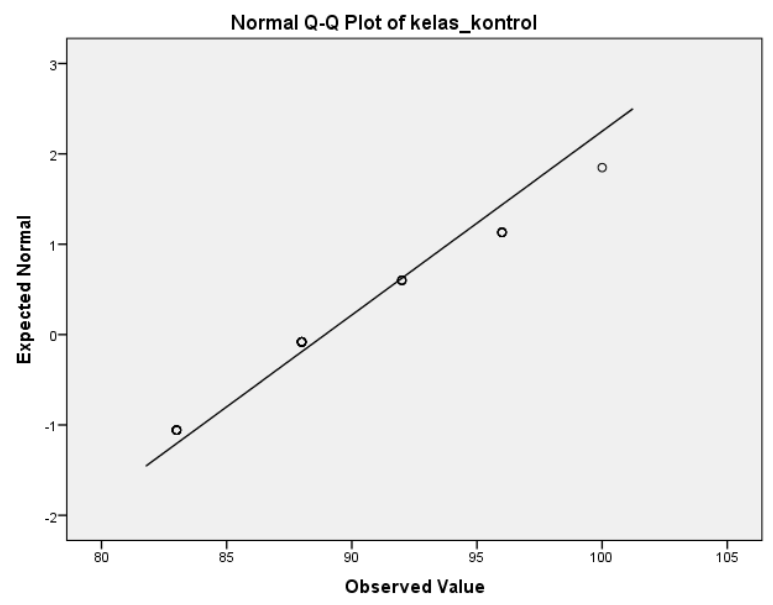

Output pada grafik di atas untuk melihat data tes akhir kelas kontrol. Distribusi data normal jika titik-titik data tersebar di sekitar garis dan mengikuti arah diagonal garis. Akan tetapi, yang terlihat dari grafik di atas titik-titik data tidak tersebar di tengah-tengah garis dan kebanyakan titik-titik data tersebut keluar dari garis. Dengan demikian, distribusi data tes akhir kelas kontrol dinyatakan tidak normal.

\section{b. Two Independent Sample Test dengan Uji Mann-Whitney Data Pascates}

Sampel berdistribusi tidak normal maka dilanjutkan pengujian non paramterik Mann-Whitney dengan menggunakan hipotesis statistik sebagai berikut:

Ho : tidak ada perbedaan kemampuan awal kelas eksperimen dan kelas kontrol Ha : ada perbedaan kemampuan awal kelas eksperimen dan kelas kontrol Kriteria pengujian:

Jika nilai sig $>0,05$ maka Ho diterima

Jika nilai sig $<0,05$ maka Ho ditolak

\begin{tabular}{|c|c|c|}
\hline & & pascates \\
\hline 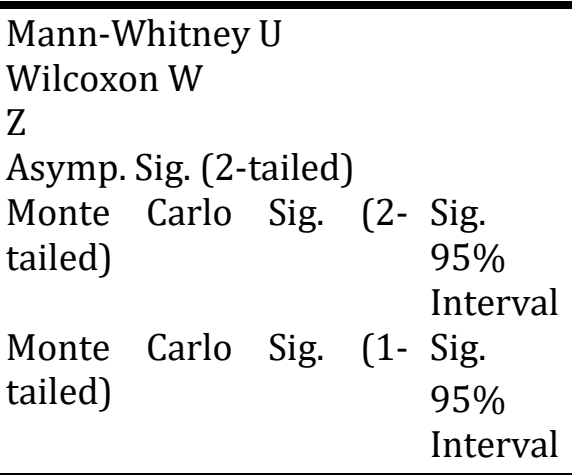 & 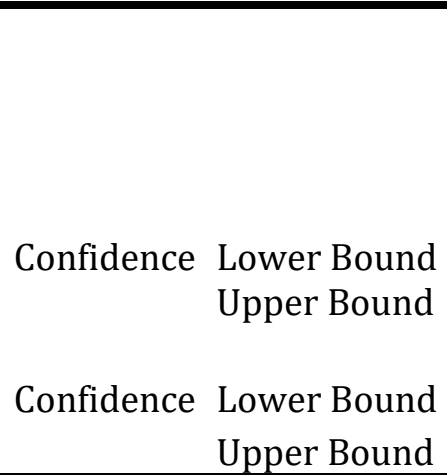 & $\begin{array}{l}183,500 \\
648,500 \\
-4,115 \\
, 000 \\
, 000^{\mathrm{b}} \\
, 000 \\
, 000 \\
, 000^{\mathrm{b}} \\
, 000 \\
, 000\end{array}$ \\
\hline
\end{tabular}

a. Grouping Variable: kelas

b. Based on 10000 sampled tables with starting seed 299883525. 
Keterangan:

Berdasarkan tabel di atas terlihat bahwa nilai signifikansi (Asymp. Sig) sebesar 0,000 atau lebih kecil dari 0,05, maka Ho ditolak, sehingga dapat disimpulkan bahwa terdapat perbedaan kemampuan akhir siswa kelas eksperimen dan kelas kontrol.

\section{Simpulan}

Berdasarkan hasil pembahasan tersebut penelitian ini dapat disimpulkan sebagai berikut:

1. Aktivitas guru dan siswa dalam pembelajaran teks anekdot dapat disimpulkan bahwa guru melaksanakan aktivitas yang mendukung pada kegiatan pembelajaran teks anekdot dengan media video animasi dengan metode quantum learning. Adapun aktivitas siswa dlihat berdasarkan kategori penilaian observasi aktivitas siswa dalam pembelajaran teks anekdot dengan menggunakan quantum learning mendapat nilai 83 dan dilihat pada tabel kategori penilaian observasi berarti baik.

2. Hasil pekerjaan siswa dalam pembelajaran teks anekdot dilihat dari hasil tes, yakni prates dan pascates (dalam dea kelas: kelas eksperimen dan kelas kontro). Berdasarkan hasil tes akhir, kelas X sebagai kelas eksperimen, setelah diberi perlakuan teks anekdot dengan menggunakan quantum learning, nilai terendah adalah 83 dan nilai tertinggi adalah 100. Siswa yang mendapat nilai tuntas sebanyak 30. Siswa. Berdasarkan hasil tes awal ini, kelas X BDP 3 sebagai kelas kontrol, sebelum diberi perlakuan teks anekdot dengan menggunakan quantum learning, nilai terendah adalah 54 dan nilai tertinggi adalah 83. Adapun siswa yang mendapat nilai tuntas sebanyak 17 siswa dan yang mendapat nilai tidak tuntas sebanyak 13 siswa. Setelah melihat hasil data tes awal (prates) menyunting teks ekplanasi, selanjutnya penulis menyajikan tabel distribusi frekuensi untuk mengetahui ratarata nilai tes awal (prates) siswa kelas X BDP 3 SMK Profita Bandung. Berdasarkan hasil tes akhir, kelas X BDP 3 sebagai kelas kontrol, sebelum diberi perlakuan teks anekdot dengan menggunakan quantum learning, nilai terendah adalah 83 dan nilai tertinggi adalah 100. Adapun siswa yang mendapat nilai tuntas sebanyak 30 siswa. Dengan demikian, hasil prates dan pascates di kelas kontrol ada perubahan yang signifikan dilihat dari nilai yang dominan meningkat. Prates di kelas kontrol mendapatkan nilai rata-rata 66,73 dan untuk nilai pascates mendapatkan nilai ratarata 67,00. Selain itu, terlihat pula peningkatan prates dan pascates di kelas eksperimen. Rata-rata prates adalah 88,93 dan rata-rata nilai pascates adalah 97,53 Setelah melakukan tes awal dan setiap kelas diberikan pembelajaran teks anekdot dengan metode yang berbeda maka akan diperoleh hasil dari tes akhir. Untuk menganalisis secara statistik hasil tes akhir (pascates) antara kelas eksperimen dan kelas kontrol, langkah-langkahnya sama seperti saat perhitungan statistik analisis tes awal (prates).

3. Hasil penilaian angket memperlihatkan jawaban dari keseluruhan angket yang dianalisis menunjukkan respon yang positif. Hal ini menandakan siswa menyukai pembelajaran teks anekdot dengan menggunakan metode quantum learning.

4. Pelaksanaan pembelajaran teks anekdot dengan menggunakan metode quantum learning sesuai dengan harapan yang diingin dicapai karena dengan menggunakan 
metode quantum learning tersebut, siswa belajar aktif ketika menyelesaikan tugas yang diberikan oleh guru.

\section{Daftar Pustaka}

Abidin, Y. (2016). Desain Sistem Pembelajaran dalam Konteks Kurikulum. Bandung: Rafieka Aditama.

Husain, A. (2019). Efektivitas Lesson Study dalam Pembelajaran Menulis Karangan Eksposisi Pada Siswa Kelas X Sekolah Menengah Kejuruan (SMK) Negeri 7 Palopo. Jurnal Onoma: Pendidikan, Bahasa, dan Sastra, Volume 5 Nomor 1, 291-313.

Kosasih, E. (2014). Jenis-Jenis Teks. Jakarta Yrama Widia.

Kurniawan, N. M., \& Sumiati, T. (2015). Pendekatan Contextual Teaching and Learning (CTL) dan Aplikasinya dalam Pembelajaran. Metodik Didaktik, 10(No. 1), 16-22. Mahsun. (2014). Teks dalam Pembelajaran Bahasa Indonesia. Jakarta: Rajawali Press. Nirwana, \& Ruspa, A. R. (2019). Penerapan Model Peta Konsep Pada Pembelajaran Menulis Karangan Argumentasi Siswa Kelas VIII SMP Negeri 7 Palopo. Jurnal Onoma: Pendidikan, Bahasa dan Sastra, Volume 5 Nomor 1, 349-368.

Potter, B. D., \& Hernacki, M. (2013). Quantum Learning: Membiasakan Belajar Nyaman Dan Menyenangkan. Jakarta: Kaifa.

Rostikawati, Y. (2014). Penerapan Model Mapping Activity dalam Pembelajaran Membaca Pemahaman. Semantik, Volume 3(No. 2), 83-94.

Suharsimi, A. (2006). Prosedur Penelitian. Jakarta: PT. Raja Grafindo Persada.

Wartomo. (2016). Peran guru dalam pembelajaran era digital. Prosiding Temu Ilmiah Nasional Guru (Ting) VIII. Paper presented at the Temu Ilmiah Nasional, Jakarta.

Wikanengsih, Isnaini, H., \& Kartiwi, Y. M. (2019). Penyuluhan Penyusunan Bahan Ajar Bahasa Indonesia yang Inovatif Bagi Guru-Guru SMP di Kabupaten Subang, Jawa Barat. CENDEKIA : JURNAL PENGABDIAN MASYARAKAT, Vol. 1 No. 2 2019, 51-58. 